\title{
The Peripherization of Ivorian Indigenous Languages: Shared Blame, What Can Be Done?
}

\author{
Dongui Zana Y. Ouattara \\ Alassane Ouattara University, Bouake, Côte d'Ivoire \\ Email: ouattdong@gmail.com
}

How to cite this paper: Ouattara, D.Z.Y. (2022) The Peripherization of Ivorian Indigenous Languages: Shared Blame, What Can Be Done?. Open Access Library Journal, 9: e8393.

https://doi.org/10.4236/oalib.1108393

Received: January 23, 2022

Accepted: February 19, 2022

Published: February 22, 2022

Copyright $\odot 2022$ by author(s) and Open Access Library Inc.

This work is licensed under the Creative Commons Attribution International License (CC BY 4.0).

http://creativecommons.org/licenses/by/4.0/

(c) (i) Open Access

\begin{abstract}
Colonization with its early language policy that has been continued and sustained by the elites was meant to spiritually subjugate the Ivorians. The elevation of the colonial language (French) by granting it official status and precedence has undeniably contributed to the peripherization of Côte d'Ivoire's local languages. This article argues that the blame for this marginalization of Ivorian local languages ought to be shared between colonization and the Ivorian people who have developed negative attitudes and an inferiority complex towards their own languages. It is time the Ivorian policy makers took bold political decisions to break with the current policy and give the local languages prominence through a new status.
\end{abstract}

\section{Subject Areas}

Language Planning, Language Policy, Sociolinguistics

\section{Keywords}

Colonization, Peripherization, Local Languages, Language Planning, Language Policy, Côte d'Ivoire

\section{Introduction}

The arbitrary and haphazard territorial boundaries imposed by the colonial masters in the last two centuries did not take cognizance of the ethnolinguistic diversities of the territories before differentiating Côte d'Ivoire from other sub-Saharan states. Consequently, the geopolitical enclave now known as a country encompasses people with varying ethnolinguistic identities. The basic truth is that colonialism and the establishment of state borders did not mind the diversity of languages spoken within Côte d'Ivoire and the heterogeneity of its linguo-cultural identities. 
The ethnolinguistic heterogeneity of Côte d'Ivoire is such that it is difficult to make an exhaustive list of the Ivorian languages. According to [1], recent criteria have permitted to number about fifty (50) indigenous Ivorian languages. For [2] and [3], there are about sixty (60) ethnic languages in Côte d'Ivoire. This multilingualism was early perceived by the French colonialists as a hindrance to their evangelical mission and grip on the new territory. To address the issue then, the language of the colonial master has ever since been used as national unifying language to the detriment of Ivorian local languages which have come to be marginalized. The prominence of the French language is such that local Ivorian languages Ivorians have been stigmatized and viewed as useless.

More and more Ivorians are inheriting the French language as their mother tongue. Investigating the problem, a survey was conducted in a primary school classroom in Bouaké1. The learners were asked two questions, what language they usually speak and whether they can speak their ethnic language or not. Out of 64 students, $34.37 \%$ said they cannot speak their ethnic language; and $38 \mathrm{pu}-$ pils, that is $59.37 \%$ asserted they usually speak French. The peripherization of Ivorian languages is perceptible, especially in urban areas. The question is who bears the blame? Should colonialism bear all the blame for the peripherization of Ivorian languages? Do the Ivorian elite and Ivorian in general not play a role in the marginalization of Ivorian languages? What can be done to redress the situation?

This paper aims at showing that the blame for the peripherization of Ivorian languages is shared between colonialism and the Ivorian elite and people. In other terms, this paper argues that both colonialism with the early language policy adopted and the attitudes of Ivorian elites and people account for the marginalization of local languages in Côte d'Ivoire.

\section{Language Planning and Policy in Cote D'Ivoire}

\subsection{Defining Language Planning}

Considering the ethnolinguistic diversity of Côte d'Ivoire, when one speaks of language planning and policy, what flashes upon the mind is the set of strategies for solving the problems triggered by a multilingual setting. As such, language planning is expected to focus on problem solving or as [4] put it, on "the formulation and evaluation of alternatives for solving language problems to find the best (or optimal, most efficient) decision." Language planning is diversely defined by different specialists. These different definitions can be narrowed down to the types of activities, namely a purely linguistic activity (corpus planning); a purely political and/or administrative activity (status planning); and language as an activity including both linguistic and political or administrative aspects.

\subsubsection{Language Planning as a Purely Linguistic Activity}

In sociolinguistics, language planning also known as language engineering in a deliberate effort to influence the function, structure or acquisition of language

${ }^{1}$ Second biggest city of Côte d'Ivoire, located in its central part. 
varieties in a heterogenous speech community. For [4], it is "the activity of preparing a normative orthography, grammar, and dictionary for the guidance of writers and speakers in a non-homogenous speech community." For [5], it is all the efforts to influence the behavior of others with respect to the acquisition, structure, or functional allocation of their language codes. Gorman considers language planning as a set of measures taken to select, codify and, in some cases, to elaborate orthographic, grammatical, lexical, or semantic features of a language and to disseminate the corpus elaborated on. [6] extends the definition to include all the normative work of language experts, all forms of what is referred to as language cultivation, and all proposals for language reform and standardization. It can be inferred that all the efforts made in this context are applied to language as a corpus, hence language planning is a purely linguistic activity which is usually considered to be a sub-discipline of sociolinguistics.

\subsubsection{Language Planning as a Political or Administrative Activity}

This implies government action as political long-sightedness interferes in the decision-making. This is stressed by [7] for whom language planning encompasses all the long-term, sustained, and conscious attempts on the part of governement to alter the role of language in a speech community. This is to say that government or administrative action is central here as language planning is perceived as government decision for solving specific language problems in a given speech community. [8] emphasizes this by defining language planning as a "political and administrative activity for solving language problems in a society." Language problems may emerge or be pending in a society or speech community; any government intervention to address those problems or hammer out long term solutions fall under the label of language planning. For [9], language planning refers to the organized persuit of solutions to language problems, typically at the national scale. To such an extent, language planning requires government action or intervention.

\subsubsection{Language Planning as an Activity Including Both Linguistic and Political Aspects}

Language planning is also an activity which operates at both the linguistic and national levels. It is an activity which intends to address a language problem on the national level; it attempts to solve a language problem usually on a national scale; and which focuses on either language form and/or language use. In other terms, the government can make a decision about the form of language or matters that are connected to its use. Language planning may lead to language change or to the assignment of a particular function to a particular language in the perspective of bringing forth a solution to language problems in a given speech community. [7] summarizes language planning as "government authorized long term sustained and conscious effort to alter a language itself or to change a language's function in a society for the purpose of solving communication problems." By the same token, [10] considers language planning as the me- 
thodological activity of a government for regulating and improving existing languages or creating new common regional, national or international languag-

es.

\subsection{Language Policy}

Language policy is part of the process of language planning. It is the implementation of language planning. As a reminder, language planning is an activity undertaken by a polity to solve a language problem. Language policy comes as the political decision or orientations to guide language planning or implement language planners proposals. As [11] puts it, the activity of language planning leads to, or is directed by the promulgation of a language policy by a government or other authoritative organization or person. A language policy for them is a body of ideas, orientations, rules and practices intended to achieve the planned language change in the speech community or system. That is to say, language policy is a set of laws, rules or regulations enacted by an authoritative body like a government in application of language planners proposals. For [12], language policy is primarily a social construct. It may consist of various elements of an explicit nature, juridical, juducial, administrative, constitutional and/or legal language may be extant in some jurisdictions, but whether or not a polity has such explicit text, policy as a cultural construct rests primarily on other conceptual elements, that is belief systems, attitudes, myths referred to as linguistic culture which is the whole of ideas, values, attitudes, prejudices, religious structures, and all the other cultural "baggage" that speakers bring to their dealings with language from their background. For Schiffman, language policy is grounded in linguistic culture and examining one without the other is "probably futile, if not simply trivial" [13]. It can be inferred from Schiffman's conception that language policy is twofold; explicit language policies enacted by a polity and language policy as a social construct which corresponds to the implicit language beliefs, attitudes, and ideologies within a speech community.

\subsection{The Linguistic Profile of Côte D’Ivoire}

It is quite difficult to determine an exhaustive number of languages in Côte d'Ivoire because the frontiers between languages and dialects are not clear-cut. Consequently, the number of languages differs from one author to another. However, the Ivorian authorities have most of the time agreed that there are about sixty (60) ethnic languages in the country. To circumvent the debate or controversy about the number of languages in the country, [14] simply classified the languages of Côte d'Ivoire into four major groups: the Manding language group, the Gur language group, the Kru language group, and the Kwa-Akan language group. The languages can also be categorized according to their social functions [14]. These four categories are 1) ethnic languages, 2) regionally dominant languages, 3) lingua franca, 4) national or official language. On top of those four categories, [15] added two other categories, namely medium languag- 
es and potential national languages.

Ethnic languages are languages which are limited to interactions between the members of the same ethnic group or family members in home settings. These languages remain vital in rural areas where often members of the same ethnolinguistic group live together (e.g. Senoufo, Bete, Baoule, Ebrie, Agni, etc.). In addition to their intra-ethnic communicative function, some languages have a remarkable dynamism and stand as means of communication region-wide. Those languages often serve as tools of intercultural or interethnic communication (e.g. Senoufo, Baoule, Bete, etc.). Language Franca are languages used on a larger geographic and functional scale. Such languages display greater dynamism than regionally dominant languages [14]. There are two Langua Franca in Côte d'Ivoire: Dioula and Popular French. Standard French stands out as the most important, official, and national language.

In addition to these four types of languages, we have medium and potential national languages as stipulated by [15]. Medium languages serve as means of communication to minority ethnic groups. In fact, the dynamism of such languages is so weak that their speakers no longer use them as their principal language when they grow old. By way of example, we have the Nafana, a language of the Gur group. On the other hand, potential national languages are major ethnic languages in the four language groups. Their scope goes beyond their natural loci and they are likely to be ranked as national languages. These languages, namely, Malinke-Dioula, Senoufo, Bete, and Baoule are susceptible to be established as languages of instruction [15]. Those languages are objects of scientific description at ILA (Institute of Applied Linguistics).

Côte d'Ivoire is a country which is characterized by ethnic diversity with multilingualism, its twin sister. Unfortunately, this linguistic potential or wealth has been brushed aside to promote French as the multi-functional language in the country. In other words, the linguistic rights of all the ethnolinguistic groups of Côte d'Ivoire have been violated since the very inception of the country's language policy at the onset of colonization. The neglect or peripherization of Ivorian ethnic languages, especially in urban areas has ever since been set on.

\subsection{Language Policy in Côte D’Ivoire before Independence}

The history of the French language dates back to colonization. Bequeathed from colonization, French language outstands as the central language in the daily life of Ivorian people. Indeed, during colonization (1890-1960), French was imposed as the official language of administration. This imposition of the French as official and national language rather than a local Ivorian language has been prompted by nationalist concerns. As [16] says:

It was felt that there were too many local languages with too few speakers who could neither understand nor tolerate each other; and that choosing any of them as a national or official language would lead to social unrest. Standard French was not only perceived as a neutral language that could politically integrate the 
diverse ethnic groups and ensure peace and national unity. It was also seen as an international means of communication, a proven medium of science and technology through which the newly independent nation could pursue its goals of development and economic prosperity.

For the sake of nation-building, the early ruling squad of Côte d'Ivoire sustained the colonial language policy which elevated the French language among the diversity to serve as a unifying factor; that is a language that all the Ivorians no matter their ethnolinguistic identities could share. The core reason is that selecting among the local languages could bring forth social unrest, which the rulers wanted to avoid. The other reasons were that French language would connect Côte d'Ivoire to the rest of the world; easier its access to the scientific and technological knowledge; trigger national development, and economic prosperity. The French language is then perceived as the neutral language that fits in for preventing conflicts. As can be seen, the national language policy of the Ivorian authorities was meant to guarantee stability; social cohesion and peaceful relations between individuals from diverse multi-ethnic and linguistic backgrounds. In a multi-ethnic setting, it is not easy to select one language among a diversity and succeed in having the other individuals from different linguistic communities accept and use it without friction. It means that the choice of the French language has been considered as a factor of unity and social cohesion in Côte d'Ivoire where about a hundred ethnic groups have been gathered by colonization. If that was true, Cote d'Ivoire would not have experienced a 10-years-long civil war from 2002 through 2011.

Another aspect which is worth mentioning here is the colonial practices regarding indigenous language policies. In fact, the colonial practices differed as a function of the colonial zone of influence. The British in their indirect rule prove more tolerant to the African languages to the point of even considering that the use of indigenous languages represented the best option to make Africans better Africans [17] and for the success of their evangelization missions. As opposed to them, the French with their colonial agenda based on their assimilation rule or direct rule resorted to all sorts of tricks to maintain the colonized as "French subjects"; so, they completely cleaned off local languages. The French Catholic Clergy conducted their evangelization mission in French essentially. In any case, the French cultural brainwashing was so efficient that some high profile African leaders like [18] had come to believe in a "congenital" superiority of the French language for science and technology over African languages he believed were just good for arts, that is poetry, music and dance. This colonial heritage continued in the aftermath of independence in Côte d'Ivoire.

\subsection{Language Policy in the Aftermath of Independence}

According to [19], the language policy of Côte d'Ivoire in the aftermath of independence is a "default language policy", that is to say not to do anything to produce change or simply defend the status quo antea. The domination of the 
French language in the Ivorian landscape has not changed after the country accessed independence on August 7, 1960. The early ruling team merely copied and pasted the language policy of the colonial administration. This is manifested by the elevation of the colonial language as official language in the constitution whose first article reads that the official language of the country is French. It was a way of establishing the primacy of French language in all public sectors. And the main reasons for this were the quest for national unity and development. It was believed that resorting to a local language among the diversity could bring forth social unrest, which they wanted to avoid. The other reason was that French language would connect Côte d'Ivoire to the rest of the world, easier access to scientific and technological knowledge which in turn would prompt development and economic prosperity. Thus, the post-independence language policy of Côte d'Ivoire was meant to guarantee stability and achieve development goals.

As can be seen, no room was granted to local languages which have to remain in the periphery. They are neither used as languages of communication in public administration nor as instruction languages in the education system of the country. Though Ivorian local languages remain strong identity markers, they enjoy no legal status and consequently are confined in the marginality of public and business sectors. It is true that they still keep some vitality especially in rural areas and in home settings in urban areas; but more and more Ivorians are using French language instead of their own ethnic languages of identification. This article argues that the blame for this is shared between colonial heritage and the ruling elite, not excluding the Ivorian people in general.

\section{The Role of Colonization in the Peripherization of Local Languages}

The role of colonialism in the peripherization of Ivorian local languages cannot be questioned. As a matter of fact, the language situation of Côte d'Ivoire has today been shaped by the former colonial master. When the French first landed in the country, they imposed their language on the people as a way of guaranteeing their effective domination and occupation of the people of Côte d'Ivoire. As a result, Ivorian languages have been backwarded for they have become inferior to French language. The ensuing outcome of this is, the peripherization or marginalization of local languages. In their assimilationist mission, the French promoted the use of French in all domains and discouraged the use of Ivorian local languages. This imposition of French was meant to brainwash the Ivorians in order to better exploit them. As [20] argues, its purpose was to transform the primitive populations of the colonies and make them useful. To do so, the best way was to instill the French language and the French ways into them from childhood. As can be seen, the French language was imposed to tighten the grip of the colonial master on Côte d'Ivoire. It was a way to submit and subject the Ivorians [21]. 
The language policy of the colonial master can be summarized as the compulsory learning of French language to the detriment of local languages; and the education system stands as the most suitable for implementing it. During the colonial period, to better disseminate and instill the French language as a tool of spiritual subjugation, the use of indigenous languages was forbidden in the classroom and even in the school yard. Learners were instructed to use French, only French; so much so that students who were caught using local Ivorian languages red-handed were punished and ridiculed with the Symbole. The Symbole was an ugly necklace that was put on the neck of the one who was caught. He had to display it everywhere in the school yard and even in the classroom. The "culprit" had to wear the Symbole and suffer the related ridicule till another student was caught in the act of using his mother tongue. The legacy of this ban on local Ivorian languages echoes in the contemporary education. The ban on indigenous languages seems to be still hovering as it is not uncommon to see some students report their peers for using mother tongues in classroom situations. The outcome of this is twofold. On the one hand, local Ivorian languages are overshadowed or relegated and the French language has been elevated with its poly-dimensional functions in Côte d'Ivoire. On the other hand, the educated Ivorians will adopt the French conception of traditional African culture [22]. This situation started since colonization and still continues, and is reinforced by the Francophonie, an international organization which regroups french speaking countries.

According to Guillou Michel [23], Francophonie is what remains of the French colonial empire and it is grounded on the French belief in the civilizing mission of French language. This ideology survives because it is backed up within African Francophone countries such as Côte d'Ivoire. On the one hand, the use of French language as both internal and transnational lingua Franca avoids the invidious choice of one local language among the diversity. On the other hand, the elite and the Ivorians in general see the acquisition of French as the condition Sine qua non of social betterment. Ivorian citizens have become enthusiastic about the French language to the detriment of their mother tongues, because it is unquestionably the language of social emancipation. At the end of the day, it is not unsual to find local people who were born and raised in Côte d'Ivoire and have never been to France but can only speak French and claim to have no knowledge of any local Ivorian language. There are countless such individuals in the urban areas of Côte d'Ivoire. This is a clear manifestation of the effects of French colonization on the psyche of Ivorians.

The language policy inherited from colonization is best promoted in the current Ivorian education system. In fact, national languages can be assessed by various indicators among which the place of local languages in national life in general and more specifically in formal education. The content of national language policies along with the roles devoted to local languages today, appear to be the consequences of two factors, namely the imposition of the colonial language 
and the dynamism of language ecosystem in Côte d'Ivoire. The imposition of colonial language pretendedly to circumvent Ivorian multilingualism echoes in the current educational system which indicates a preference for French language as the medium of instruction. Once French was declared the language of education and officialdom, it was put in the privileged position causing the linguistic competition to be in its favor at the expense of local languages which are marginalized. In terms of choosing and utilizing indigenous languages in education, former British colonies are more advanced than their French counterparts. By contrast in the former colonies, even when a nationwide indigenous language is available, the pervasive influence of the assimilationist rule generally hinders any language policy that is directed to elevate it and include it in the education system as a medium of instruction. Even though African scolars have stubbornly kept on urging policy makers to institutionalize indigenous languages as media of instruction, as critical input achieving culturally motivated development strategies likely to guarantee sustainability, their actual insertion in the education system has yet to become a reality.

To wrap up, the general philosophy of the French colonists is one which aimed at spiritually subjugating the Africans by destroying or stigmatizing their languages. This eventually brought about the neglect or marginalization of indigenous languages including the Ivorian local languages, especially in urban areas where the demand for French language as an asset for social achievement is stronger; in other words, where the colonial language is more prominent. The major thrust of the French people was to spiritually subjugate Africans; that is destroy their "soul" and replace it with their own language, culture, ways, and thinking. Language is very important in controlling or maintaining control over people. As [24] posits, controlling people through language is one element in maintaining control over them. To be more specific, with the violation of their linguistic right and their subsequent poor performance in the imposed language, people are vulnerable; they become easily managed as they are unable to express their thoughts. Control is then more easily maintained at the linguistic level than through brute force. This means that the control of former French colonies by brute force would not sure have been as successful as with the violation of the linguistic rights. The imposition of French language appears to have been the optimal way to subjugate the people of Côte d'Ivoire.

It is true that colonization through its language policy has played a determining role in the peripherization of local languages in Côte d'Ivoire. However, should it bear all the blame? Does the attitude of the Ivorian elites and the Ivorian people not also account for the neglect or marginalization of Ivorian local languages? As a reminder, the purpose of this paper is to show that the blame for the marginalization of Ivorian local languages is shared between colonial heritage and the attitudes of the Ivorian elite and people towards local languages. What is the responsibility of the latter then? 


\section{The Responsibility of the Ivorian Elite and People}

Colonialism alone cannot bear the blame for the neglect of Ivorian local languages. There are other reasons that account for the peripherization of Ivorian languages especially in urban areas. The negative attitudes of the Ivorian elite in particular and the Ivorians in general are to be reckoned here. First of all, this sad state of affairs is linked to the fact that the early country's rulers and policy makers also wrongly perceived Ivorian multilingualism as a problem rather than an asset. As the colonialists, they also believed that choosing and elevating a local Ivorian language out of the diversity would cause social friction. Consequently, they continued with the colonial language policy to the detriment of Ivorian local languages. Besides, they did not want to make any effort to develop and standardize a local language and give it official status. They felt it was no need as the colonial language, French was already entrenched and it has the advantage of being already developed and easy to implement in all aspects of governance.

Moreover, one may also suspect the Ivorian elite of promoting what [25] referred to as "elite closure". According to Scotton, elite closure is linguistic divergence created as a result of using a language which is only known to or preferred by the elite. This divergence may be purposeful. To such an extent, forcing the common people to use a colonial language that they have not mastered well is one way of limiting the masses from accessing state resources, easily controlling and exploiting them. The latter, since they are shown the demeaning role of local languages, will come to view their own ethnic languages as useless. They want to be communicatively functional and thus avoid being discriminated against and staying at the margin of the system. This resulting disregard for local languages halts the intergenerational transmission of linguistic and cultural traditions. Many Ivorians associating their disadvantaged social position with their culture end up believing their languages are not worth retaining. This is much more perceptible in urban areas where even some families will no longer use their ethnic languages for interacting in family settings. As [26], puts it, "they abandon their languages and cultures in hopes of overcoming discrimination, to secure livelihood, and enhance social mobility or to assimilate to the global marketplace."

As can be noticed, the current attitudes and perceptions of indigenous languages in Africa are to a large extent attribuable to a show of class among the elite as well as the colonial language policies which independent African states including Côte d'Ivoire have been unable to change considerably. With the benefits of hindsight, one can opine that the African elites and the neo-colonial administration in many African states like Côte d'Ivoire neglected and did not made optimum use of local languages even when they are aware of the important role of those languages in national development and shaping identity. Rather as [27] and [28] argue, African rulers have initiated language polices that have pushed local languages to the backseat and promoted the use of Western European languages such as French as languages of government, education and 
that of the elites. In general, post-colonial educational policies were deliberately aimed at currently making Africans including Ivorians view their languages as inferior and less competent while holding the colonial languages in high esteem. Such positions have vigorously been challenged by scholars like [29]; yet the new ruling teams of African states still continue in the tradition of the colonial masters showing the masses that the knowledge of colonial languages is an important weapon in the search for employment, class and privileges. The mastery of foreign languages like English, French, German or else has a major contribution to one's advancement [27]. The knowledge of French and other foreign languages opens doors for the future. [30] opines that within the education system, most students see very little value in learning African languages. For example, most of the participants in [28] held that they see very little to be gained in future especially in the job market and social betterment by studying Kswahili.

It is apparent that the Ivorian elite are not doing enough or are simply doing nothing to promote the use of indigenous languages. They simply promote the continuation of the language policy adopted since independence. It is worth noting that alongside the elite, the teeming Ivorian masses are falling or have fallen into the "trap" as they develop negative attitudes towards Ivorian languages. Regettably, their attitudes towards their own languages also play a role in the peripherization of local Ivorian languages. As a reminder, it is generally accepted by many Africans that there are no incentives linked to learning and mastering local languages. Parents including those from low income brackets will advocate for their children to be taught colonial languages instead of indigenous ones because of the economic benefits associated with the former. It is this general attitude towards local languages that often makes it difficult for some states to fully establish legal and policy framework aimed at elevating African languages to the same level as their European counterparts.

In African countries like Côte d'Ivoire, it is not unusual to see parents praise their children on their linguistic achievement or mastery of the colonial language whereas the latter cannot even utter a single word in their related mother tongue. This manifestation of the outcome of colonialism on the psyche of Ivorians goes hand in hand with a complex of inferiority they have developed for everything African including their ethnic languages. The centuries of French colonialism have resulted in Ivorians feeling lesser of themselves and having less confidence in Ivorian local languages. The continuous use of the colonial language and the prestige attached to it in Ivorian institutions is a manifestation of this anomaly. One of the reasons advanced by some advocates of colonial languages is that African languages lack the terminology to be used in courts, they lack the scientific and technological, political and legal terms. But a language such as French has borrowed extensively its legal and scientific terms from Greek and Latin.

In the light of all that have been said in this section, it can be inferred that the Ivorian people in general and the ruling elite in particular have also contributed 
in the marginalization of Ivorian local languages. The ruling elite has simply reinforced the colonial language policy by elevating the French language to the detriment of local languages which end up suffering neglect. In Côte d'Ivoire, the Ivorians have developed negative attitudes and feeling towards their own ways, languages and cultures they often find silly and useless. Something ought to be done to address this sad situation.

\section{Intervention}

\subsection{The Necessity to Do Something}

According to [31], development cannot be possible in the former French colonies without great usage of indigenous languages in the pursuit of scientific, artistic and cultural change. If the language policy adopted had been successful, Côte d'Ivoire would not have still been toddling on the way to development. Countries like Korea, Japan and Malaysia for instance have developed mainly because of the advantage of their own languages. Actually, there is no country anywhere in the world (except in Africa) where the most important, most prestigious and the most powerful activities of the nation are conducted in what is for most of the citizens, a foreign language [32]. This is why also, most of the poorest countries in the world are in Africa. No country can develop outside its language. It is worth noting that much of our thinking is facilitated by language. The thinking which seems to involve language is the reasoned thinking which takes place as we work out problems, tell stories and plan strategies.

Language is not only a means of communication. It also facilitates thinking [33]. This demonstrates the need to elevate one of our local languages as official language, language of media, broadcasting, education, literature, to mention just a few. If we succeed in using indigenous languages, it naturally follows that our thinking patterns and the masses will be taken into account in the participatory development whose produced solutions will be relevant to the context of our country. We ought to elevate the local languages of Côte d'Ivoire. Using one's own language is seen as a right. This right was reinforced by the 1966 Barcelona universal Declaration on linguistic right that emphasized non-discrimination, pluralism and community initiatives in language use. When people's linguistic rights are acknowledged, the full participation of masses in all national activities such as judicial and administrative proceedings, civil service, examinations, voting and public employment is guaranteed. Language is therefore one of the most precious possessions of mankind for it is the principal factor that enables the individuals to become functioning members of the group they were born into [34]. As such, nations are able to develop because language provides an important link between people and their environment. Language is an indispensable feature of the cultural systems of all societies as it penetrates into all aspects of social, economic, political and religious spheres. [35] adds that language has a dual character. It is both a means of communication and a carrier of culture. It is a means of interactions with society as well as repository of a people's culture, 
values, aspirations and beliefs. He adds that a nation cannot survive without a concurrent linguistic expression. Thus, one should agree with [36] that no other language can effectively displace one's mother tongue; and that there is a danger of extinction of Ivorian local languages looming if we continue over-blowing the importance of French language at their expense.

Aside the efforts of linguists, contemporary philosophers side with the opinion that philosophy cannot live up to its pragmatic role in social reconstruction in Africa unless it takes cognizance of the importance of African indigenous languages. This is in line with [37] who argues in favor of a development catalyst called "conceptual decolonization" that prioritize African indigenous languages to take the lead role in the search of development. It is also in line with the tradition that [35] resolved to do scholarship solely in African languages before translating into other languages. The choice of French as the official and national language of Côte d'Ivoire is wrong as the Ivorian masses are excluded in the process of development. Classifying African states as French, English, and Portuguese makes very little sense especially when you consider the percentages of people who can actually function in those languages. Consequently, it is foolhardy to continue with a language policy that gives the French language precedence in Côte d'Ivoire, unless we want to continue excluding the masses [30]. It is therefore urgent and imperative that indigenous languages should be studied and put to everyday use with the intention to show their logical structure and that everyone is welcome on board to contribute meaningfully and participate in government and development [38]. What can be done? Can one suggest the need to rejuvenate Ivorian local languages? It is a must. Then, how does this operate?

\subsection{What Can Be Done}

In order to destigmatize local languages in Côte d'Ivoire, politicians, opinion leaders, entertainers, popular artists including the ruling elite should speak them from time to time to kind of set an example to the Ivorians who feel unconformtable using them in public or Ivorians who have already abandoned their mother tongues. Ivorian media should also broadcast in local languages. It is true that local languages are often heard on the national media, but not with much or enough airtime to encourage Ivorians into granting them significant importance. The assigned airtime is a function of the current policy which promotes French language as the sole language of media in Côte d'Ivoire. This ought to change. Many programmes should be included and broadcasted in local languages in the Ivorian media. Every year, some audio-visual programmes such as WOZO with Ivorian ethno-cultural aspects are organized during the holidays for children aged through 15. Unfortunately, the language of this programme is French. Local languages are rarely used by children in the programme. It would be wise to insert them as the languages of this programme; this would raise children's awareness to the importance of local languages. For boosting local 
languages during this programme, children or groups of children who show mastery of cultural and local languages can be egged on with big rewards. This implies the adhesion of the ministry of cultural affairs.

There are four (4) dominant languages in Côte d'Ivoire, the news should be broadcast in these languages first before being translated into French. This means that French language should always come after the Ivorian local languages. The media are generally very powerful tools in propagating ideologies; and Ivorian media have the advantage of blindly following the policies of the working governments. If the state rulers agree to promote local languages in the media, this will appear as chicken feed, seen the strength of Ivorian media.

Besides, the use of the dominant languages of Côte d'Ivoire should be established in the administration, especially in the regional headquarters of the national administration. The policy makers of Côte d'Ivoire can start with this. If it proves successful, one of these languages can be elevated as national language in the country. An animal's legs do not all move at the same time; they move one after the other. A good language policy cannot be successful if it is not applied in the education system. There have already been attempts to include the regionally dominant languages as means of instruction in the education system of Côte d'Ivoire. In 1977, a reform Bill $\mathrm{N}^{\circ} 77-584$ was passed by the parliament to include the Senoufo, Baoule, Dioula and Bete languages as instruction languages in the education system. ILA, the Institute of Applied Linguistics was assigned the task of describing the languages scientifically and providing didactical material. They did their work; unfortunately, none other bill was passed on how this would actually be applied in the education system. There had been a lack of political will to apply the bill. Later on, in 1978, ILA tried including mother tongues in some 15 nursery schools. The results were encouraging; however, this project was locked away because of the lack of political will and a "supposed" possible high cost of implementation.

On the one hand, the Ivorian ruling elite should make bold political decisions, break the umbilical cord with the colonial power (France) and boldly face the possible drawbacks of this rupture. On the other hand, they should invest much in the key sectors that can develop the country. African governments in general invest millions of dollars to equip their armies and stay in power as long as possible. These misused big amounts of money can be invested in the field of language planning in the perspective of promoting local languages in Côte d'Ivoire. The peripherization of Ivorian local languages should cease; and this will come true if political will and significant financial means are spared for that. According to [39], language is like a currency; the more it can buy, the greater its value. If we agree with this assertion, the logical inference is that we should promote Ivorian local languages by giving them greater market value in vital sectors of public life and public policy (administration, politics, education, and economics). In other terms, language policies and development policies, projects and programmes should be bound together. No matter what may be officially 
declared in favor of promoting Ivorian languages, they will remain marginal and the masses who can communicate only in those languages will remain marginalized too as far as organizing and running public life and state affairs are concerned if action is not met with words. An optimal strategy to promote Ivorian local languages should include integrating language planning and language policies into development projects considered vital to the country.

Furthermore, the folk perception of the superiority versus inferiority complex must cease. One of the effect of the marginalization of local Ivorian languages is the superiority and inferiority status glued on the French and Ivorian local languages respectively. Ivorian languages are stigmatized and looked down on. People have levelled negative attitudes and preceptions against them; whereas, the French language acts as "access for success" as it is used in all facets of life. Ivorian people should merely stop nursing a superiority-inferiority complex respectively for French language and Ivorian languages. This should go along with spousing positive attitudes towards local languages, ways and cultures in general. They ought to stop viewing African languages as inferior and African ways or cultures as silly and outdated. Likewise, they should stop underestimating African languages as assets and tools of development and grow confidence in everything African. This can be possible through sustained nationwide campaigns of sensitization. In Côte d'Ivoire, this role can be assigned to the ministry of culture to set up, organize and implement sensitization missions at the national scale. Opinion leaders, politicians, teachers, entertainers can also help in the process by adopting a positive attitude towards Ivorian languages.

Moreover, the Institute of Applied Linguistics has already been working on Ivorian languages. The policy makers of Côte d'Ivoire should provide financial support to prompt their work and help them provide local languages with orthography. This will be a watershed in the promotion of local languages. As [40] puts it "an endangered language will progress if its speakers can write their language down." A language that has dictionaries, grammars, and other materials developed in them have better chances of survival and maintenance than those that do not. [41] points out that, in the present day society, a language which is written down has a greater chance of surviving because without orthography and literacy materials, a language cannot be taught and handed down from one generation to another.

The cost of language development and standardization cannot be a hindrance if one considers the millions of dollars the government members embezzle; the millions of dollars they spend on military equipment and tactics to stay in power as long as possible. On top of this if one considers the hundreds of millions of dollars allotted to Ivorian president to serve as President's Fund and the unecessary amount of money squandered on the pleasure of governments officials, there is no reason that Côte d'Ivoire cannot fund such a project. It just takes bold political will, decision, and reduced lust or crave for power to make the development and standardization of local Ivorian languages. Of course, Côte 
d'Ivoire will not have to develop and standardize all the languages at the same time. We can kick off with the major or regionally dominant languages.

\section{Conclusion}

In conclusion, it is glaring that Ivorian local languages are peripheralized, especially in urban areas, media, and education as a result of the continuation of the early colonial language policy in Côte d'Ivoire and the negative attitudes of Ivorian leaders and the Ivorians in general. It is high time the local languages were rejuvenated. We recommend that the Ivorian policy makers match implementation with words by adopting policies that would promote the use of local languages by all sundry including the masses and leaders. A good starting point would be to develop and adopt the regionally dominant languages that are cross-ethnic and have a wider scope or base in their respective regions, and also retain French language in a minor role. This is within reach as Côte d'Ivoire has the wherewithals, resources and trained linguists available. It will just require a bold political will and decision.

\section{Conflicts of Interest}

The author declares no conflicts of interest.

\section{References}

[1] Ahoua, F. (2006) Ivory Coast: Language Situation. In: Brown, K., Ed., Encyclopedia of Language \& Linguistics, Elsevier Science, Amsterdam, 72-76. https://doi.org/10.1016/B0-08-044854-2/01639-4

[2] Pfurscheller, L. (2015) Le developpement d'une langue nouvelle: Lenouchi une langue mixte de la Côte d'Ivoire. Quo Vadis Romania, 45, 81-92.

[3] Aboa, A.L. (2007) Le Français: Langue coloniale ou Ivoirienne? Herodote, $\mathrm{N}^{\circ} 126$, 23.

[4] Rubin, J. and Jernudd, B. (1971) Can Language be Planned? Sociolinguistic Theory and Practice for Developing Nations. University of Hawaii Press, Honolulu.

[5] Cooper, R.L. (1989) Language Planning and Social Change. Cambridge University Press, Cambridge.

[6] Haugen, E. (1969) The American dialects of Norwegian. University of Pennsylvania Press, Philadelphia.

[7] Weinstein, B. (1980) Language Planning in Francophone Africa. Language Problems and Language Planning, 4, 55-77. https://doi.org/10.1075/lplp.4.1.04wei

[8] Jernudd, B.H. and Das Gupta, J. (1971) Towards a Theory of Language Planning. In: Rubbin, J. and Jernudd, B.H., Eds., Can Language be Planned: Sociolinguistic Theory and Practice for Developing Nations, University of Hawaii Press, Honolulu, 185-204. https://doi.org/10.2307/j.ctv9zckn9.15

[9] Fishman, J.A. (1974) Advances in Language Planning. De Gruyter Mouton, the Hague. https://doi.org/10.1515/9783111583600

[10] Tauli, V. (1974) The Theory of Language Planning. In: Fishman, J., Ed., Advances in Language Planning, De Gruyter Mouton, the Hague, 49-69.

https://doi.org/10.1515/9783111583600.49 
[11] Kaplan R.B. and Baldauf, R.B. (1997) Language Planning from Practice to Theory. Multilingual Matters, Clevedon.

[12] Schiffman, H. (1996) Linguistic Culture and Language Policy (The Politics of Language). Routledge, London.

[13] Schifffman, H.F. (1995) Language Shift in the Tamil Communities of Malaysia and Singapore. Southwest Journal of Linguistics, 14, 151-165.

[14] Djité, P.G. (1989) French in the Ivory Coast. The French Revue, 62, 494-504.

[15] Lafage, S. (1982) Esquisse des Relations interlinguistiques. Bulletin de PObservation du Français contemporain en Afrique Noire, $\mathrm{N}^{\circ} 3$, 9-27.

[16] Djité, P.G. (2006) Shifts in Linguistic Identities in a Global World. Language Problems and Language Planning, 30, 1-20. https://doi.org/10.1075/lplp.30.1.02dji

[17] Prah, K.K. (2000) African Languages for the Mass Education of Africa (CASAS Book Series $\mathrm{N}^{\circ} 7$ ). 2nd Edition, The Centre for Advanced Studies of African Society, Cape Town.

[18] Senghor, L.S. (1986) African Sojourn: Ue Ommer. Arpel Graphics, Santa Barbara.

[19] Calvet, J.L. (2016) The Geopolitics of Romance Languages. Hermès, La Revue, 2, 25-33.

[20] Hardy, G. (1917) Une conquête morale: L'Enseignement en AOF. Armand Colin, Paris.

[21] Aboa, A.L. (2008) La Francophonie vécue en Côte d'Ivoire. In: Société Internationale pour l'Histoire du Français Langue Etrangère ou Seconde, Document pour 1 Histoire de la langue Francaise, SIHFLES, Paris, 27-34.

[22] Chung, P. (1996) Africa: A Fresh Start. The UNESCO Courier, Paris, 29-31.

[23] Guillou, M. (1995) La mangue et la Pomme: Voyages en Francophonie. John Libbey Eurotext, Paris.

[24] Kargalitsky, B. (2010) Controlling People through. Moscow Times.

[25] Myers-Scotton, C. (2010) Comparing Codeswitching and Borrowing. Journal of Multilingual and Multicultural Development, 13, 19-39.

https://doi.org/10.1080/01434632.1992.9994481

[26] UNESCO (2003) Language Vitality and Endangerment. Presented at the International Expert Meeting on UNESCO Programme Safeguarding of Endangered Languages. UNESCO Ad Hoc Expert Groups on Endangered Languages, Paris.

[27] Ishola, A. (2010) Limits of Tolerance: The Future of African Cultures. Making Culture Memorable: Essays on Language, Culture and Development. Hope Publications, Ibadan.

[28] Mohodi, E.S. (2005) Language and Regional Integration: Foreign or African Languages for the African Union? In: Yieke, F.A., Ed., East Africa: In Search of National and Regional Renewal, CODESIRA, Dakar, 41-54.

[29] Alafoyan, A. (1976) The Six Year Primary Project in Nigeria. In: Bamgbose, A., Ed., Mother Tongue Education: The West Africa Experience, Hodder and Stoughton, London, 133-134.

[30] Bamgbose, A. (1983) Education in Indigenous Languages: The West African Model of Language Education. The Journal of Negro Education, 52, 57-64.

https://doi.org/10.2307/2294748

[31] Mazrui, A. (2002) The Asmara Declaration on African Languages: A Critical Reappraisal. A Keynote Address Delivered at the Annual Conference of Linguistics Held at Ohio University, Athens, $\mathrm{OH}$. 
[32] Kishindo, P.J. (2000) Language and Development. The Lamb, 2, 14-15.

[33] Ogutu, E.A. (2006) Mother Tongue amidst Other Languages: Planning Roles in the Classroom and Outside. In: Mutasa, D.E., Ed., African Languages in the 21 st Century: The Main Challenges, SG Publishers, Pretoria, 36-59.

[34] Mutasa, D.E. (2004) People Speak: Language Policy and Language Use in South Africa. SG. Publishers, Pretoria.

[35] Ngugi, W. (1986) Decolonizing the Mind. Zimbabwe Publishers House, Harare.

[36] Ogunsij, A. (2001) Utilitarian Dimension of Language in Nigeria. In: Igboanusi, H., Ed., Language Attitude and Language Conflict in West Africa, Enicrownfit Publishers, Ibadan, 152-164.

[37] Wiredu, K. (1997) The Need for Conceptual Decolonization in African Philosophy. Studies in International Philosophy, 3, 11-22,

[38] Oladipo, O. (1996) Philosophy and the African Experience. Hope Publications, Ibadan.

[39] MacKay, W.A. (1984) Education Law in Canada. Edmond Montgomery Publications Ltd., Toronto.

[40] Crystal, D. (2000) Language Death. Cambridge University Press, Cambridge.

[41] Visser, H. (2000) Language and Cultural Empowerment of the Khoesan People: The Naro Experience. In: Batibo, H.M. and Simeja, B., Eds., Botswana: The Future of Minority Languages, Peter Language, Frankfurt, 193-216. 